\title{
Overin dev mikst tip seks kord stromal tümörü
}

\author{
Ovarian huge mixed sex cord stromal tumor
}

\author{
Mine Genç¹, Serap Karaarslan², Neslin Şahin ${ }^{3}$, Ali Saklamaz ${ }^{4}$, Belkıs Uyar ${ }^{5}$, Serkan Güçlü ${ }^{1}$
}

\section{ÖZET}

Seks kord stromal tümörler; tüm over tümörlerinin yaklaşık \%7'sini oluştururlar. Sertoli-Leydig hücreli tümörler ve granüloza hücreli tümörler overin seks kord stromal tümörlerinin alt tiplerindendir. Sertoli-Leydig hücreli tümörler, tüm over tümörlerinin \%0,2-0,5'den daha azını oluştururlar. Granüloza hücreli tümörler ise tüm over tümörlerinin \%3-5'ini oluştururlar. Seks kord stromal tümörün alt tiplerinin birlikte izlenmesi ise çok çok nadir bir durumdur. Bu nedenle bu güne kadar literatürde çok az sayıda vaka bildirilmiştir. Seks kord stromal tümörler tanı konulduğunda büyük kitleler halinde olmasına rağmen, \%80-90'ının evre 1'de olduğu gözlenmektedir. Olgumuz 2 aydır devam eden pelvik ağrı, menoraji, giderek artan karın şişliği ve alopesi şikayetleri olan 21 yaşında nullipar hastadır. Hastanın pelvik ultrasonografi ve manyetik rezonans görüntülemelerinde sol overde $175 \times 170 \times 93$ mm boyutlarında septalı kistik kitle izlenmiştir. Kistinin septalı olması ve fertilite koruyucu cerrahinin istenmesi nedeniyle sol unilateral salpingooeferektomi uygulanmıştır. Histopatolojik incelemede mikst tip (Granüloza hücreli/Sertoli-Leydig hücreli tümör) seks kord stromal tümör olarak değerlendirilmiştir. Bu olgu nadir görülmesi ve klinik özellikleri nedeni ile yayınlamaya uygun bulunmuştur.

Anahtar kelimeler: Granüloza hücreli tümör, manyetik rezonans görüntüleme, over, Sertoli-Leydig hücreli tümör

\section{GíRiş}

Overin seks kord stromal tümörleri nadir görülen over neoplazmlardır ve primer over tümörlerinin $\% 7$ 'sini oluştururlar [1]. Bu tümörlerin büyük ço-

\section{ABTRACT}

Sex cord-stromal tumors account for approximately $7 \%$ of all primary ovarian tumors. Sertoli-Leydig Cell Tumors and Granulosa cell tumors are subtype of sex cord stromal tumor of the ovary. Sertoli-Leydig Cell Tumors account for less than $0.2-0.5 \%$ of all primary ovarian neoplasms. Granulosa cell tumors account for $3-5 \%$ of all primary ovarian neoplasms. Mixed subtype of sex cord stromal tumors are very rare a condition. Very few case reports have been documented in the literature so far. Despite the rather large lesion at the time of diagnosis in sex cord stromal tumors, $80-90 \%$ of patients will present at stage 1. A case of 21-year-old nullipar woman who presented with a 2-month history of a pelvic pain, menorrhagia, rapidly increasing abdominal distention, and alopecia. Pelvic ultrasonography and magnetic resonance imaging revealed $175 \times 170 \times 93 \mathrm{~mm}$ septal cystic mass in the left ovary. The patient underwent left unilateral salpingoophorectomy because of huge septal cystic mass and fertility preserving surgery. In histopathological examination these masses were evaluated as mixed (Granulosa cell/Sertoli-Leydig Cell Tumors) sex cord stromal tumor. This case was chosen and reported due to its rarity and clinical properties.

Key words: Granulosa cell tumor, magnetic resonance imaging, ovary, Sertoli-Leydig cell Tumor ğunluğu düşük dereceli tümörlerdir [2]. Overin seks kord stromal tümörleri histopatolojik olarak granüloza hücreleri, teka hücreleri, Sertoli hücreleri, Leydig hücreleri ve stromal kökenli fibroblastlardan gelişebilir. Genellikle tek hücre grubundan oluşur

\author{
${ }^{I}$ Şifa Üniversitesi Tıp Fakültesi Kadın Hastalıkları Ve Doğum AD, İzmir, Türkiye \\ ${ }^{2}$ Şifa Üniversitesi Tip Fakültesi Patoloji AD, İmir, Türkiye \\ ${ }^{3}$ Şifa Üniversitesi Tip Fakültesi Radyoloji AD, Izmir, Türkiye \\ ${ }^{4}$ Şifa Üniversitesi Tip Fakültesi Endokrinoloji Ve Metabolizma Hastalıkları Bilim Dall, İzmir, Türkiye \\ ${ }_{5}^{5}$ Şifa Üniversitesi Tip Fakültesi Dermatoloji AD, İzmir, Türkiye \\ Yazışma Adresi /Correspondence: Mine Genç, \\ Şifa Üniversitesi Tıp Fakültesi Kadın Hastalıkları Ve Doğum AD, İmir, Türkiye Email; doktorminegenc@gmail.com \\ Geliş Tarihi / Received: 02.11.2014, Kabul Tarihi / Accepted: 21.01.2015 \\ Copyright @ Dicle Tıp Dergisi 2015, Her hakkı saklıdır / All rights reserved
}


veya nadiren çeşitli kombinasyonları izlenebilir. Sertoli-Leydig hücreli tümörler (SLHT) tüm over tümörlerinin \%0,2-0,5'ini granüloza hücreli tümörler (GHT) ise tüm over tümörlerinin \%3-5'ini oluştururlar [3-5].

Biz bu yazımızda çekilen görüntüleme yöntemlerinde benign over kistleri ile karışan 21 yaşında genç kızdaki mikst tip seks kord-stromal tümörü sunmaktayız.

\section{OLGU SUNUMU}

Yirmi bir yaşında nullipar hasta, 2 aydır devam eden uterin kanama, alopesi, karın ağrısı ve karında şişlik şikayeti ile hastanemize başvurdu. Hastanın pelvik ultrasonografik incelemesinde sol adneksial alanda 175x170x93 mm boyutlarında multilokule internal ekojeniteler ve kalın septalar içeren kistik yapı izlendi. Hastanın çekilen manyetik rezonans görüntüleme (MRG) incelemesinde distalde mesaneyi iten, proksimalde umblikusu aşan 20x18x10 $\mathrm{cm}$ çaplı düzgün kontürlü, içinde yer yer ince septasyonlar bulunan multilobule, multikistik kitlesel lezyon izlendi (Resim 1). Radyolojik olarak solid komponent ayırt edilemedi ve genel özellikleriyle seröz kist adenom olarak yorumland 1 . Hastanın kan tahlilerinde demir eksikliği anemisi ve hipotiroidi ( Hb: 8.7 g/dl, Htc: \%27,3, Plt: 403 103/ul, Ca125: 14 U/ml, TSH: 8.44 uIU/ml) dışında özellik saptanmadi. Sol adneksial kitle ön tanısıyla laparatomi yapılan olgunun batın eksplorasyonunda sol adneksten köken alan ve diyafram altına kadar uzanan çevre dokularla yapışıklık oluşturmamış, içerisinde kalın septaları olan ve seröz vasifta sıvı bulunan kistik kitle izlendi. Sol salpingoooferektomi uygulanarak frozen için patoloji bölümüne gönderildi. Sağ over ve batın içerisindeki diğer organlar normal olarak izlendi. Kitlenin makroskopik incelemesinde $22.5 \times 18 \times 5.5 \mathrm{~cm}$ boyutlarında olduğu ve kapsülünün intakt olduğu görüldü. Kesit yapıldığında içerisinden seröz nitelikte sıvı boşaldı. Multikistik özellikte olan overde fokal kanamalı ve solid-kirli, sarı-beyaz renkte alanlar mevcuttu (Resim 2). Frozen parafin olarak değerlendirildi. Genel özellikleri seks kord stromal tümör ile uyumlu olmakla birlikte GHT ve SLHT arasında ayırıcı tanı yapılamadığ Sol unilateral salpingo ooforektomi yapılan hastada fertilite koruyucu cerrahi gerekliliğinden işleme son verildi.
Mikroskobik olarak değişik morfolojik özellikler sergileyen fibro-tekamatöz stromaya sahip tümörde; trabeküler yapılanma ve diffüz yapılanma oluşturmuş granüloza hücreli tümör alanları yanı sıra, solid kord yapıları, diffüz patern, retiform alanlar ve pirimitif gonadal stroma taşıyan Sertoli hücreli tümör alanları dikkati çekti. Heterelog eleman izlenmedi. Her iki komponentte de arada luteinize özellikte teka hücreleri mevcuttu. Tümörde diffüz patern oluşturmuş odaklarda mitotik indekste artma ve atipi dikkati çekmekteydi (10 büyük büyütme alanında 20'den fazla mitoz). Büyük büyütmede GHT alanlarında tümör hücre nükleusunda kahve çekirdeği görünümü taşıyan fokal odaklar dikkati çekti. İmmünohistokimyasal (İHK) incelemede her iki tümör alanında da inhibin ve vimentin pozitif, CD99 ile ise GHT alanlarında pozitiflik saptandi. Ki-67 proliferasyon indeksi mitotik indeksin arttığ 1 alanlarda \%25 olarak değerlendirildi (Resim 2 ve 3). Ayırıcı tanı için yapılan EMA, pansitokeratin, CD30, $\alpha \mathrm{FP}$, PLAP ve sinaptofizin boyamalarında özellik saptanmadı. Vaka morfolojik ve İHK veriler eşliğinde mikst tip seks kords stromal tümör (GHT "jüvenil tip" ve SLHT "intermedier diferansiye") olarak değerlendirildi. Aradaki az diferansiye odakların ayırıcı tanısı net olarak yapılamadı.

Onkoloji konseyinde hastanın evresi 1 a olarak kabul edildi ve 3 aylık klinik takiplerle izlenmesine karar verildi.

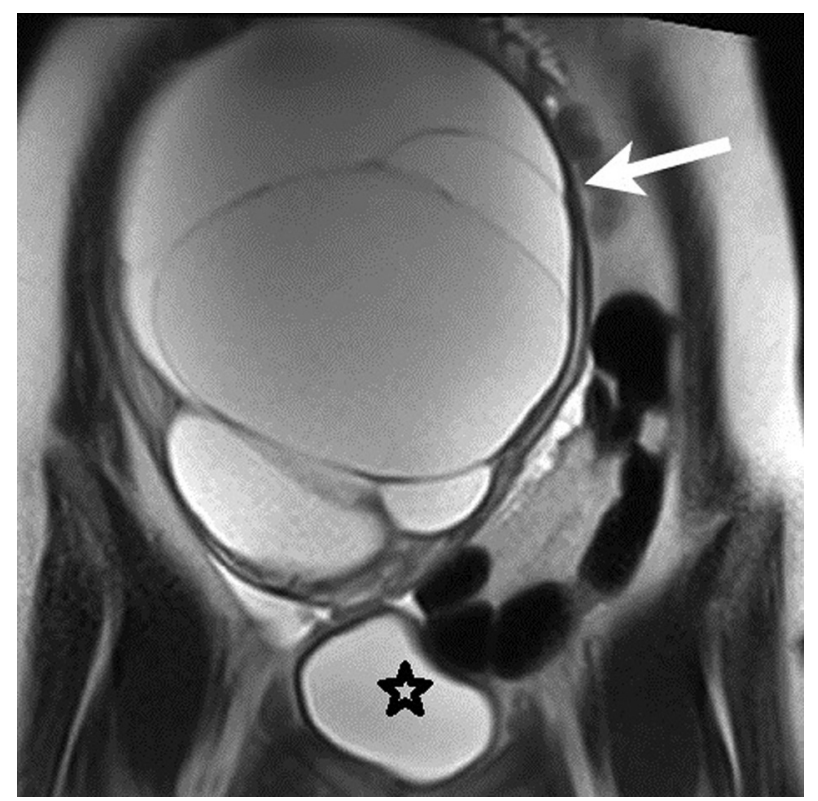

Resim 1a. T2 ağırlıklı koronal kesitte hiperintens, 


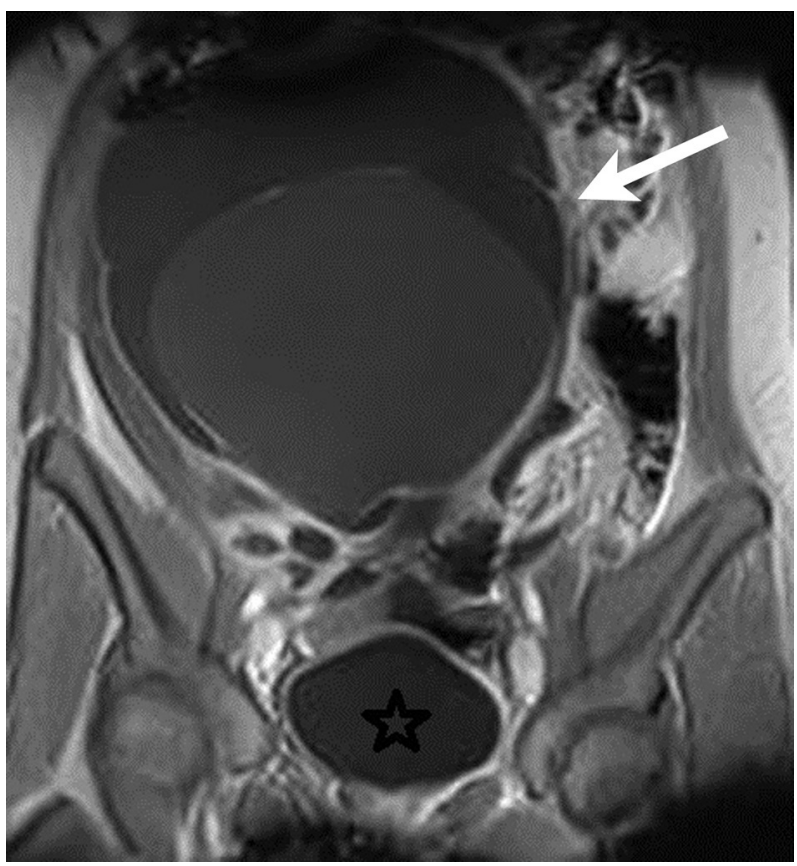

Resim 1b. T1 ağırlıklı koronal ve

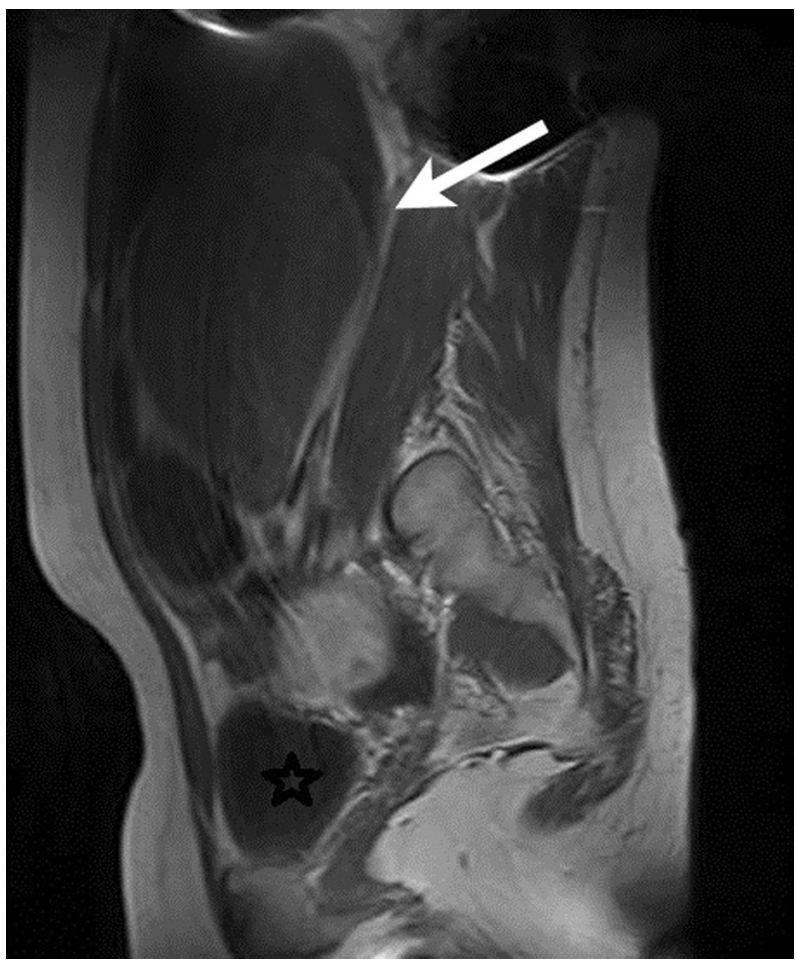

Resim 1c. T1 ağırlıkı sagital kesitlerde hipointens kitlesel oluşum görülmektedir (beyaz ok). Lezyon septasyonludur ve farkı kompartmanlardaki içeriği de özellikle T1 ağırlıklı kesitlerde farklı sinyal intensitesi göstermektedir.

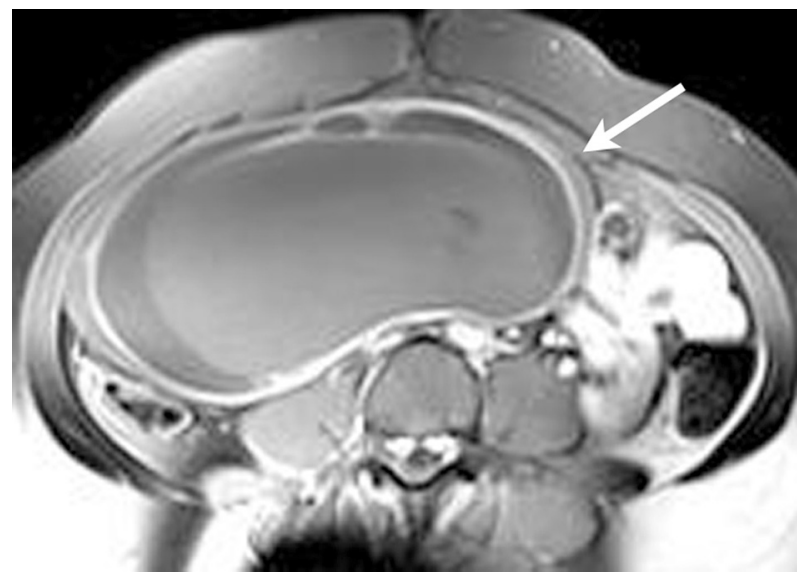

Resim 1d. Postkontrast yağ baskılamalı aksiyel görüntülerde lezyonun kapsülü ve septaları düzgün kontrast tutmaktadır. Lümene uzanan polipoid yapı görülmemiştir ve lezyonun içinde solid komponent mevcut değildir.

Resim 1 a-d. 21 Yaşındaki bayan hastanın kontrastlı batın MRG incelemesinde distalde mesaneyi (siyah yıldız) iten, proksimalde umblikusu aşan 20x18x10 cm çaplı

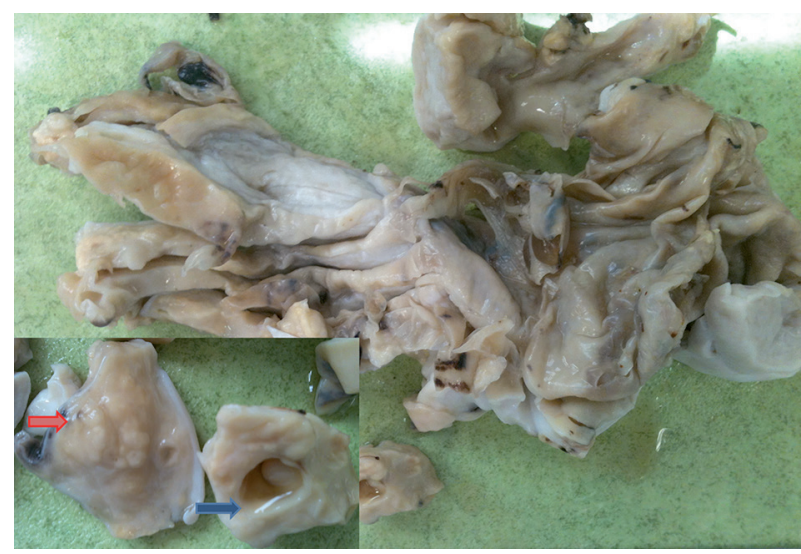

Resim 2. Makroskopik olarak büyük çoğunluğu değişik çaplarda kistlerden oluşan tümörde, arada solid, kirli-sarı renkte, düzgün sınırlı alanlar (küçük resim) dikkati çekmektedir.

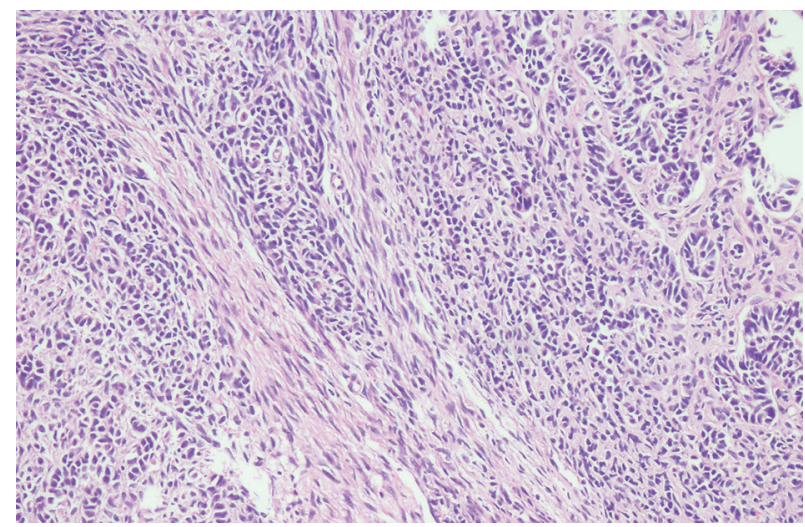

Resim 3a. Granüloza hücreli tümör alanlarında trabeküler yapılanma gösteren alanlar (sol üst-orta) ve Sertoli-Leydig hücreli tümör alanları (sağ üst) (H\&Ex100). 


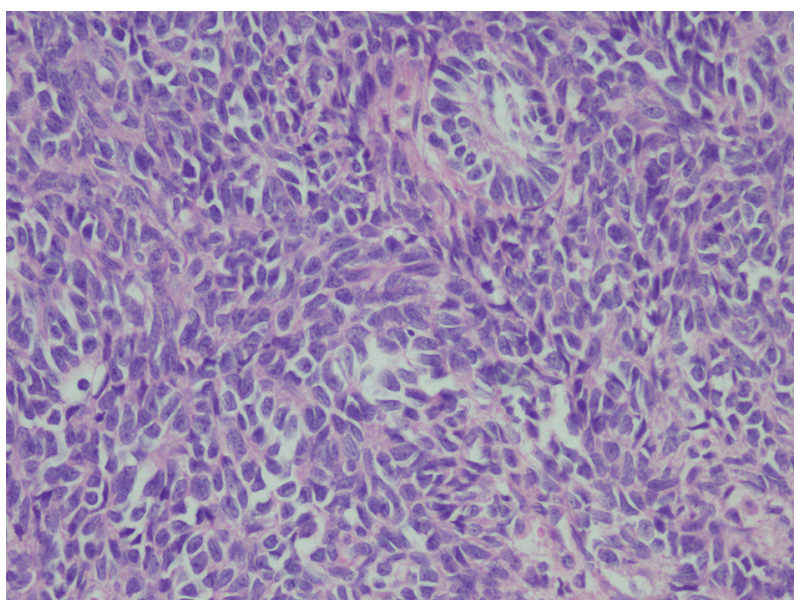

Resim 3b. Aynı resmin büyük büyütmesinde granüloza hücreli tümörde nükleuslarda kahve çekirdeği görünümü (H\&Ex200).

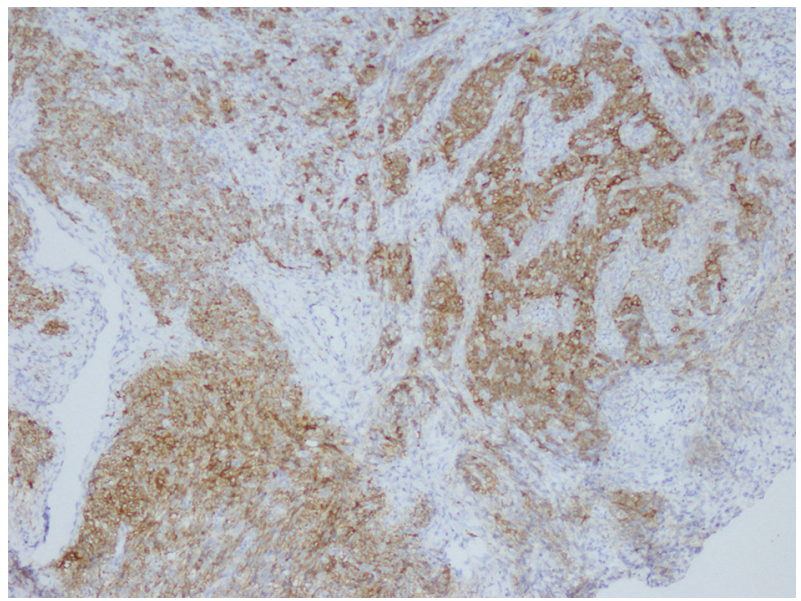

Resim 3c. İmmünohistokimyasal incelemede granüloza hücreli ve Sertoli-Leydig hücreli tümör alanlarında inhibin pozitifliği (DAPx100).

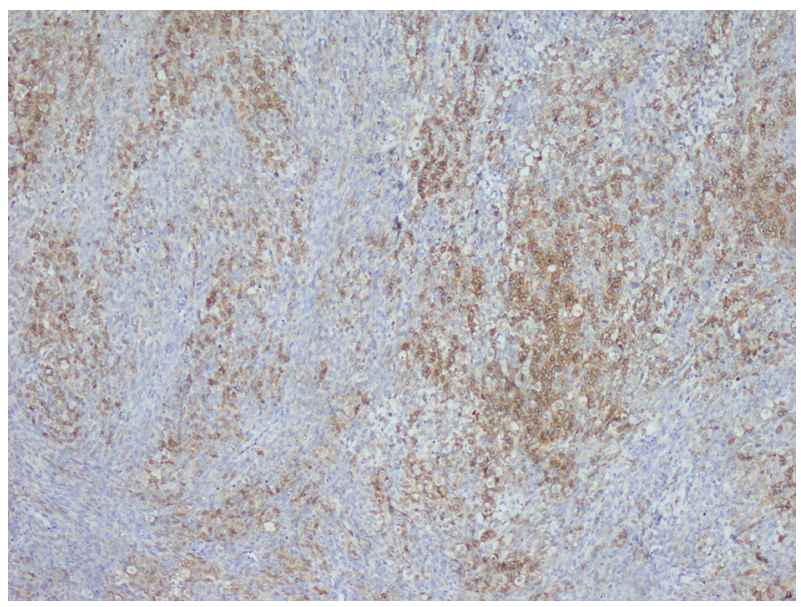

Resim 3d. İmmünohistokimyasal incelemede granüloza hücreli tümör alanlarında CD99 pozitifliği (DAPx200).

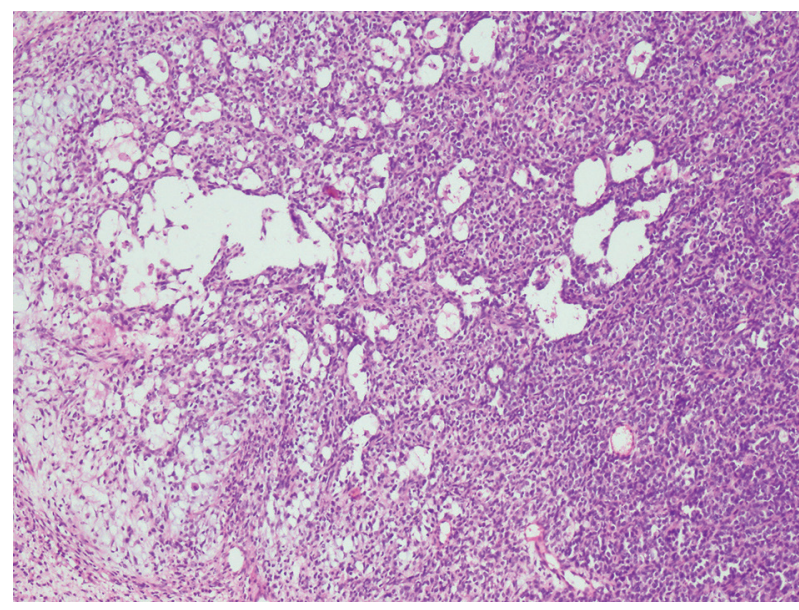

Resim 4a. Retiformpatern sergileyen Sertoli-Leydig hücreli tümör alanları ve çevresinde yoğun ödemli stroma (H\&Ex100).

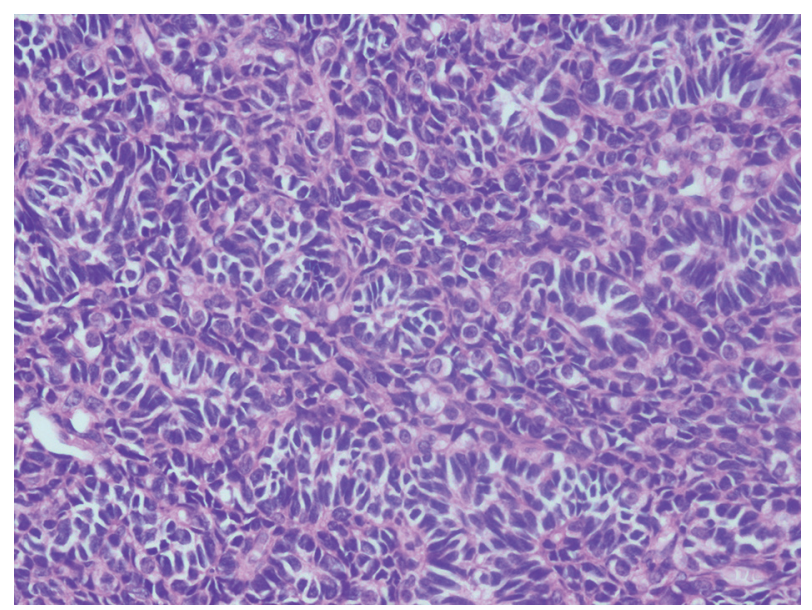

Resim 4b. Az diferansiye tümör alanlarında diffüz, solid yapılanma alanlarında atipi ve aradaki stromada luteinize teka hücreleri görülmekte (H\&Ex200).

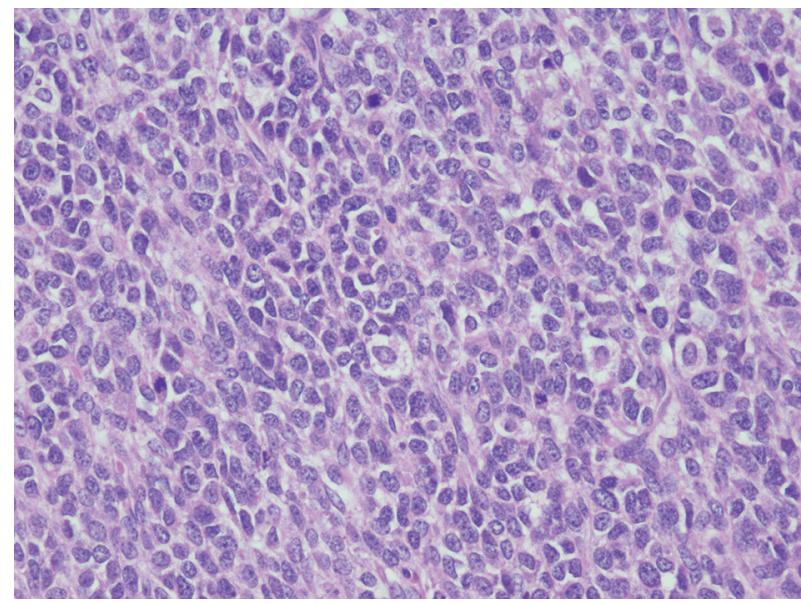

Resim 4c. Diffüz patern oluşturmuş odaklardaki artmış mitotik indeks (H\&Ex200). 


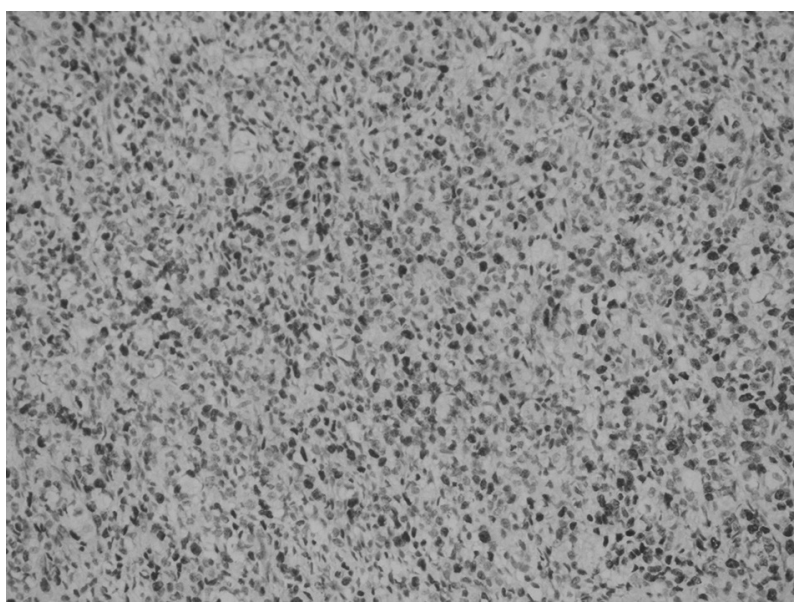

Resim 4d. İmmünohistokimyasal incelemede Ki-67 proliferasyon indeksi \%25 olarak değerlendirildi (DAPx200).

Resim 4 a-d. Sertoli-Leydig hücreli tümör alanlarının özellikleri.

\section{TARTIŞMA}

Overin seks kord stromal tümörleri nadir olup, tüm over malignitelerinin \%7'sini oluştururlar [1]. Androblastoma olarak ta bilinen SLHT, overin seks kord stromal tümörlerindendir. SLHT'ler tüm over tümörlerinin \%0.2-0.5'ini oluştururlar [4, 5]. İyi diferansiye, orta diferansiye, az differansiye ve heterolog elemenlar içeren tip olmak üzere dört alt gruba ayrilırlar [4]. En s1k izlenen alt grubları intermediate ve kötü diferansiye tipleridir [4]. Düşük-grade biyolojileri nedeni ile FIGO (International Federation of Gynecology and Obstetrics, FIGO) siniflamasina göre genellikle evre 1'de tanı konulur [4]. GHT'ler ise tüm over tümörlerinin \%3-5'ini oluştururlar [3-5]. Adult ve jüvenil olarak 2 alt tipi mevcuttur. Jüvenil tip premenarş döneminde ve genç yaşlarda görülürken, erişkin tip postmenopozal dönemdeki kadınlarda görülür. Jüvenil tip tüm GHT'lerin $\% 5$ 'ini oluşturur [1]. GHT'lerde genellikle FIGO sinıflandırmasına göre evre 1'de tanı alırlar. Bizim hastamızda overinin kapsülü intakt olup, patolojik incelemesinde solid ve kistik alanlardan oluşan tümör izlendi. GHT ve SLHT komponenti yanı sıra solid alanlarda hücresel atipinin ve mitozun arttığ 1 jüvenil GHT ve/veya az diferansiye SLHT odakları görülmüştür. Hastanın evresi, evre 1 (FIGO) olarak kabul edildi. SLHT \%75 olgu 30-40 yaş arasında olup, nadiren genç erişkinlerde görülür [6]. Bizim olgumuz 21 yaşında idi.
Hastaların yaklaşık \%30'unda virilizasyon bulguları olmasına rağmen çoğu hastada ana semptom pelvis içerisinde büyüyen kitlenin varlığıdır. Genel olarak hastalarda testosteron, androstenodion düzeyleri artar, östrojen düzeyi genellikle normaldir ya da nadiren artabilir. Literatürde multinodüler guatr ile birlikte olan SLHT vakaları bildirilmiştir [7]. Bu tür vakalarda genetik olarak DICER-1 mutasyonu saptanmıştır [8]. Bizim hastamızda alopesi dışında herhangi bir virilizasyon bulgusuna rastlanılmamıştır. Hastamızın 2 aydan beri devam eden vaginal kanamasına sekonder olduğu düşünülen derin anemisi ve hipotiroidisi vardır. Hastada var olan alopesi, anemi ve hipotiroidiye bağlı olabilir.

Ultrasonografi ve MRG'de solid ya da kistik alanlar, kalın septalar izlenebilir. Solid alanların görülmesine bağlı fibrotekoma ile kistik alanların görülmesine bağlı olarak da seröz kist adenom ile karışabilir [9]. Bizim hastamızda da uygulanan görüntüleme yöntemleri sonrasında ön tanı olarak seröz kist adenom düşünülmüştür. Literatürde tümör çapının tanı konulduğunda ortalama $13 \mathrm{~cm}$ olduğu ve şu ana kadar tespit edilen en büyük tümör çapının $51 \mathrm{~cm}$ olduğu bildirilmiştir [4] .Bizim olgumuzda tanı konulduğunda tümör çapı ortalama $20 \mathrm{~cm}$ idi.

Tedavide fertilite arzusu olan kadınlarda tek taraflı ooferektomi yapılması yeterlidir [5]. Fertilite arzusunu tamamlamış kadınlarda nadiren bilateral (\%1 olguda bilateraldir) olması nedeniyle bilateral ooferektomide uygulanabilir.

Bizim vakamızda tümör tek overde sinırlı ve kapsül invazyonu yoktu. Peroperatif yapılan frozen parafin olarak değerlendirildi. Over tümörlerinde bazı durumlarda tanı parafin takip sonrasına birak1lır [10]. Bizim hastamızda fertilizasyonunu tamamlamadığ 1 için unilateral salpingooforektomi yapıld 1 . Postoperatif 12. aya kadar olan takiplerinde nüks saptanmadi.

Sonuç olarak, Mikst özellikte seks kord stromal tümörler, nadir görülen over tümörlerindendir. Klinik olarak nonspesifik özellikler sergileyen vakalar, görüntüleme yöntemlerinde overin benign tümörleri ile karışabilirler. Her zaman virilizasyona yol açmayabilir. Fertilite arzusu olan kadınlarda tek taraflı ooferektomi yeterlidir. 


\section{KAYNAKLAR}

1. Haroon S, Zia A, Idrees R, et al. Clinicopathological spectrum of ovarian sex cord-stromal tumors; 20 years' retrospective study in a developing country. J Ovarian Res 2013;6:87-93.

2. Koonings PP, Campbell K, Mishell Jr, et al. Relative frequency of primary ovarian neoplasms: a 10-year review. Obstet Gynecol 1989;74:921-926.

3. Schumer ST, Cannistra SA. Granulosa cell tumor of the ovary. J Clin Oncol 2003;21:1180-1189.

4. Young RH, Scully RE. Ovarian Sertoli-Leydig cell tumors. A clinicopathological analysis of 207 cases. Am J Surg Pathol 1985;9:543-569.

5. Gui T, Cao D, Shen K, et al. A clinicopathological analysis of 40 cases of ovarian Sertoli-Leydig cell tumors. Gynecol Oncol 2012;127:384-389.
6. Alam K, Maheshwari V, Rashid S, et al. Bilateral SertoliLeydig cell tumour a rare case report. Indian J Pathol Microbiol 2009;52:97-99.

7. Chi M, Gilman AD, Iroegbu N. Management of metastatic ovarian Sertoli-Leydig cell tumor with sporadic multinodular goiter: a case report and literature review. Future Oncol 2011;7:1113-1117.

8. Frio TR, Bahubeshi A, Kanellopoulou C, et al. DICER1 mutations in familial multi-nodular goiter with and without ovarian Sertoli-Leydig cell tumors. JAMA 2011;305:68-77.

9. Cai S, Zhao S, Qiang J, et al. Ovarian Sertoli-Leydig cell tumors: MRI findings and pathological correlation. J Ovarian Res 2013;26:73.

10. Alabalık U, Avcı Y, Keleş AN, et al. Five year evaluation of intraoperative pathology consultations in a university hospital. Dicle Med J 2013;40:207-211. 